\title{
THE ROTIFERS OF HEARD ISLAND: PRELIMINARY SURVEY, WITH NOTES ON OTHER FRESHWATER GROUPS
}

\author{
by Herbert Dartnall
}

(with two tables and seven text-figures)

Dartinal.., H. J. G., 1995 (30:vi): The rotifers of Heard Island: Preliminary survey, with notes on other freshwater groups. Pap. Proc. R. Soc. Tasm. 129: 7-15. https://doi.org/10.26749/rstpp.129.7 ISSN 0080-4703. Copper Beeches, 76 Lewes Road, Ditchling,

Sussex BN6 8TY, UK; formerly Australian Antarctic Division, Kingston, Tasmania.

Twenty rotifers (three Bdelloidea and 17 Monogononta, including new species of Encentrum and Notholca), a platyhelminth, gastrotrich, two nematodes, two tardigrades, one enchytraeid worm, four cladocerans, two copepods and three species of mites were recovered from five small pools on Heard Island. The results indicate that the Heard Island fauna is closer to that of Signy Island and Macquarie Island than to that of the much nearer Kerguelen archipelago.

Key Words: rotifers, Heard Island, zoogeography, sub-Antarctic islands.

\section{INTRODUCTION}

Heard Island $\left(52^{\circ} 58^{\prime}-53^{\circ} 12^{\prime} \mathrm{S}: 73^{\circ} 15^{\prime}-73^{\circ} 51^{\prime} \mathrm{E}\right)$ is a small "turtle-shaped" island situated in the southern Indian Ocean, approximately halfway between South Africa $(4850 \mathrm{~km}$ to the west) and Australia (4350 km to the east), and $1650 \mathrm{~km}$ north of the Antarctic Continent (fig. 1). The main body of the island consists of a mountain, Big Ben, topped by a volcanic peak rising to $2745 \mathrm{~m}$. Much of the island is heavily glaciated, the climate severe and, at sea-level, average temperatures only marginally above freezing. The island was first sighted 1833 and was subsequently exploited by sealers (Headland 1989).

A number of the early Antarctic expeditions visited the island, and from 1948 until 1955, a small meteorological base was maintained there by the Australian National Antarctic Research Expeditions (ANARE). Since then, several private expeditions, as well as periodic visits by members of ANARE, have taken place (Headland 1989). On one of the latest of these (January 1991), five freshwater pools were sampled, and the results obtained are presented here.

\section{MATERIALS AND METHODS}

\section{Collection and Examination Procedures}

In very shallow pools, the plastic collecting bottles ( 1 litre) were filled simply by immersing them. In deeper water $(>0.3 \mathrm{~m})$, the bottles were filled from a handnet $(0.36 \mathrm{~m}$ cone made of $53 \mu \mathrm{m}$ mesh), which was swirled through the water. In both cases, the samples were augmented with small scoops of benthic vegetation. All of the samples were collected on 31 January 1991 and were stored at $4^{\circ} \mathrm{C}$ prior to examination five days later at Davis Station, where they were filtered through a $20 \mu \mathrm{m}$ mesh and then examined under a dissecting microscope.

Permanent slides were made using polyvinyl-lactophenol, following the method of Russell (1961). The pH (Corning $\mathrm{pH}$ meter model 240) and the conductivity (Microprocessor Conductivity Meter model LK196) of the filtrate was determined.

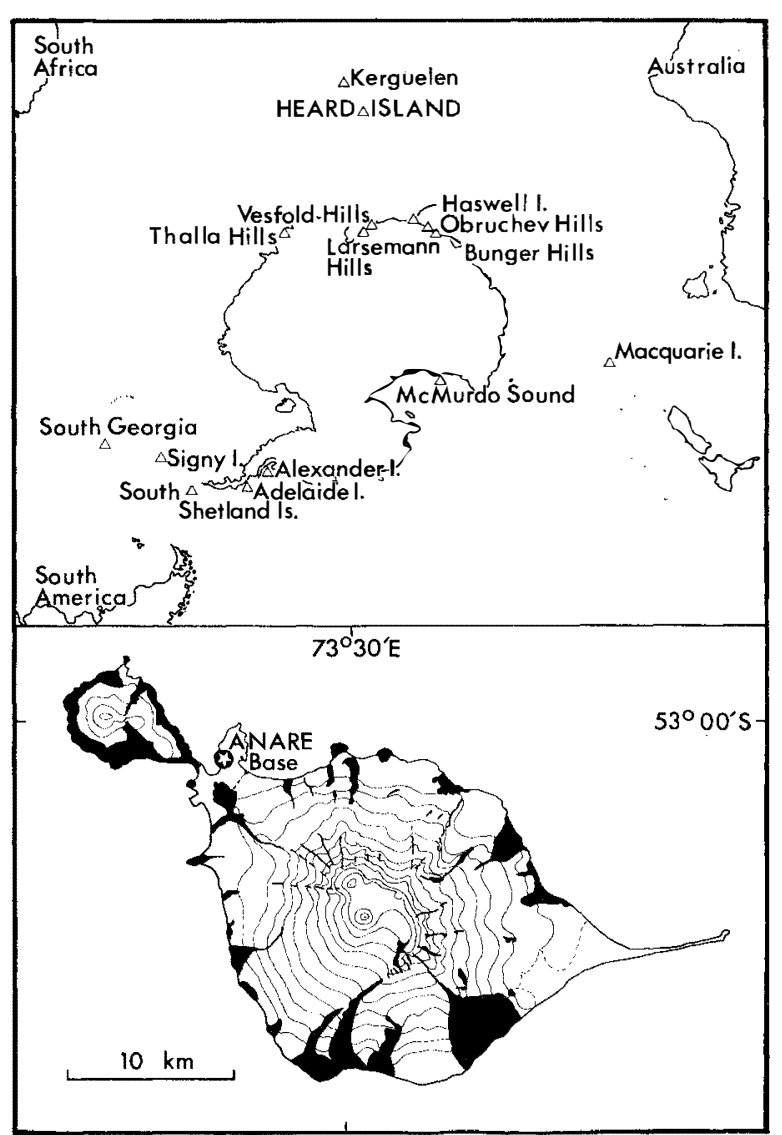

FIG. 1 - Upper: map showing Heard Island and all the other Antartic and sub-Antarctic locations mentioned in the text. Lower: map of Heard Island showing the position of the old ANARE base; the black areas are exposed rock; the thin lines mark the $200 \mathrm{~m}$ ice contours and the broken line the limit of the ice field. 


\section{Study Sites}

Five pools, located some $200-400 \mathrm{~m}$ to the east of the old ANARE meteorological base on Atlas Cove (fig. 1), were samp led. Here, there were numerous bodies of water amongst the cushion plants (Azorella selago) and tussock grass (Poa cookiz). All were small and shallow, the largest one sampled being some $4 \mathrm{~m} \times 6 \mathrm{~m}$ and just $0.5 \mathrm{~m}$ deep. Details of the size of each pool, its approximate distance from the old ANA RE meteorological base and other pertinent information are given in table 1 .

\section{RESULTS}

\section{Identification of the Fauna}

The collection, which was made as an adjunct to a survey of rotifers from the Australian Antarctic Territories, contained a number of other invertebrates. Since the freshwater fauna of Heard Island is very poorly known, brief notes on all species found are included. Their distribution in the five pools is given in table 2 .

\section{Protozoa}

Protozoa were observed in all of the samples with benthic vegetation and mostly consisted of small spherical, and elongate, colourless ciliates. A few large paramecium-type ciliates were seen; testate amoebae (Arcellasp.) were observed amongsts algal filaments (Spirogyra sp., Vaucheria sp. and Zygnemasp.). Suctoria and vorticellids decorated the shells of many of the cladocerans.

\section{Platyhelminthes}

Several specimens of a large non-eyed acoel were seen in three of the pools (Nos 1, 4 and 5).

\section{Gastrotricha}

Only two specimens were seen in sample 4 . Both were covered in fine sensory bristles (Chaetonotus sp.).

\section{Tardigrada}

Tardigrades were found amongst the benthic vegetation. Two species have subsequently been identified: a Dactylobiotussp. and Hypsibiussp. (probably H. antarcticus).

\section{Nematoda}

Nematodes were found in all of the scoops of benthic vegetation. Two species were recognised but have not yet been identified.

\section{Rotifera}

Twenty species of rotifer were found - seventeen Monogononta and three Bdelloidea. Only Habrotrocha sp. was found in every sample. Eleven species were found at just one location.

\section{Monogononta}

Epiphanes senta (0. F. Muller) (fig. 2A)

This large $(>600 \mu \mathrm{m})$ illoricate species was found only in sample 5 , where it was fairly common. The corona bears several tufts of strong cilia. The mastax has malleate trophi, and each uncus bears five principal teeth and several minor ones (fig. 2A). Males were not seen. The specimens found are in close agreement with the published descriptions and measurements for this species (Koste 1978).

Epiphanes senta is cosmopolitan and is usually found in small pools enriched with excreta of domestic animals. In

TABLE 1

Details of the five pools sampled

\begin{tabular}{|c|c|c|c|c|c|}
\hline $\begin{array}{l}\text { Pool } \\
\text { no. }\end{array}$ & $\begin{array}{l}\text { Distance to east } \\
\text { of ANARE base }(\mathrm{m})\end{array}$ & $\begin{array}{l}\text { Size } \\
(\mathrm{m})\end{array}$ & $\begin{array}{l}\text { Depth } \\
\text { (m) }\end{array}$ & $\begin{array}{l}\text { Sampling } \\
\text { method* }^{*}\end{array}$ & Pool environment \\
\hline 1 & 200 & $2 \times 1$ & 0.35 & A, B & Surrounded by tussock grass and cushion plants \\
\hline 2 & 200 & $6 \times 4$ & 0.50 & $\mathrm{C}$ & Surrounded by tussock grass and cushion plants \\
\hline 3 & 400 & $4 \times 1$ & 0.30 & $2 \times A, C$ & - \\
\hline 4 & 400 & $3 \times 1$ & 0.30 & $2 \times \mathrm{A}, \mathrm{C}$ & Pool rich with filamentous green algae \\
\hline 5 & 400 & $4 \times 1$ & 0.10 & $2 \times \mathrm{A}, \mathrm{B}$ & $\begin{array}{l}\text { Surrounded by cushion plants, bare earth/mud, } \\
\text { frequented by elephant seals }\end{array}$ \\
\hline
\end{tabular}

* $\mathrm{A}$ = be nthic scoop, $\mathrm{B}=$ immersion sample, $\mathrm{C}=$ plankton net. 
TABLE 2

Distribution* of invertebrates in the five pools on Heard Island

\begin{tabular}{|c|c|c|c|c|c|}
\hline Pool & No. 1 & No. 2 & No. 3 & No. 4 & No. 5 \\
\hline $\mathrm{pH}$ & 7.01 & 6.52 & 6.05 & $6: 48$ & 6.53 \\
\hline Conductivity $\mu \mathrm{S} / \mathrm{cm}$ & 161 & 135 & 184 & 174 & 265 \\
\hline Protozoa & + & + & + & + & + \\
\hline Plathyhelminthes & + & - & - & + & + \\
\hline \multicolumn{6}{|l|}{ Gastrotricha } \\
\hline Chaetonotussp. & - & - & - & + & - \\
\hline \multicolumn{6}{|l|}{ Tardigrada } \\
\hline Dactylobiotus sp. & - & - & + & + & + \\
\hline Hypsibius antarcticus? & + & - & + & + & - \\
\hline Nematoda & + & - & + & + & + \\
\hline \multicolumn{6}{|l|}{ Rotifera } \\
\hline Cephalodella sterea & + & - & - & - & - \\
\hline C. ventripes & - & - & - & + & - \\
\hline Collotheca ornata cornuta & - & - & - & + & + \\
\hline Colurella colurus compressa & - & - & - & + & - \\
\hline Encentrum heardensis & + & - & - & - & + \\
\hline E. mustela & + & - & - & + & + \\
\hline Epiphanes senta & - & - & - & - & + \\
\hline Euchlanis sp. & - & - & - & + & + \\
\hline Lepadella patella & - & - & - & + & - \\
\hline L. triptera & - & - & - & + & - \\
\hline Lindia torulosa & + & - & - & + & - \\
\hline Notholca bollowdayi & + & - & + & + & - \\
\hline Notommata glyphura & - & - & - & + & - \\
\hline Ptygurasp. & - & + & - & - & + \\
\hline Resticula gelida & - & - & - & - & + \\
\hline Rhinoglena frontalis & - & + & + & - & + \\
\hline Trichocerca brachyura & - & - & + & + & - \\
\hline Adineta sp. & - & - & - & + & - \\
\hline Habrotrochasp. & + & + & + & + & + \\
\hline Rotatoria rotatoria & - & - & - & + & - \\
\hline \multicolumn{6}{|l|}{ Annelida } \\
\hline Enchytraid worm & + & - & + & + & + \\
\hline \multicolumn{6}{|l|}{ Arthropoda } \\
\hline "Chydorid" 2 spp. & - & + & + & + & + \\
\hline Macrothrix sp. & - & + & + & - & - \\
\hline Daphniopsis studeri & - & + & + & + & - \\
\hline Pseudoboeckella remotissima & + & + & + & + & - \\
\hline Harpacticoid $\dagger$ & - & - & - & + & - \\
\hline Alophagus antarcticus & + & + & + & - & + \\
\hline Halozetes marinus? & + & - & - & + & - \\
\hline P.auberti occidentalis & + & - & - & - & - \\
\hline
\end{tabular}

* Key: + present, - not found

$\dagger$ According to Smith \& Sayers (1971) the Heard Island harpacticoid is Epactophanes richardi antarcticus (Richters).

the Antarctic, it is found in pools enriched by penguins and seals. It has been reported from the McMurdo Sound area (Murray 1910, Armitage \& House 1962, Dougherty \& Harris 1963); from fresh and brackish pools in eastern Antarctica, in the Bunger Hills (Korotkevich 1958), at Haswell Island (Kutikova 1958, Donner 1972), and in the Larsemann Hills (Dartnall 1995); from the South Shetland Islands (de Paggi 1982) and the South Orkney Islands (Dartnall \& Hollowday 1985); and from the sub-Antarctic Macquarie Island (Dartnall 1993)
Rhinoglena frontalis Ehrenberg (fig. 2B, C)

This was the commonest species in sample 2. A few specimens were also seen in samples 3 and 5 . It is a large $(>400 \mu \mathrm{m})$, slow-swimming species with two tiny toes. The corona is elongated dorsally into a rostrum that bears two prominent eye-spots. The mastax has malleate trophi and each uncus has seven teeth. This is a viviparous species and many specimens were carrying a single developing young. The specimens found are in close agreement with the published descriptions 


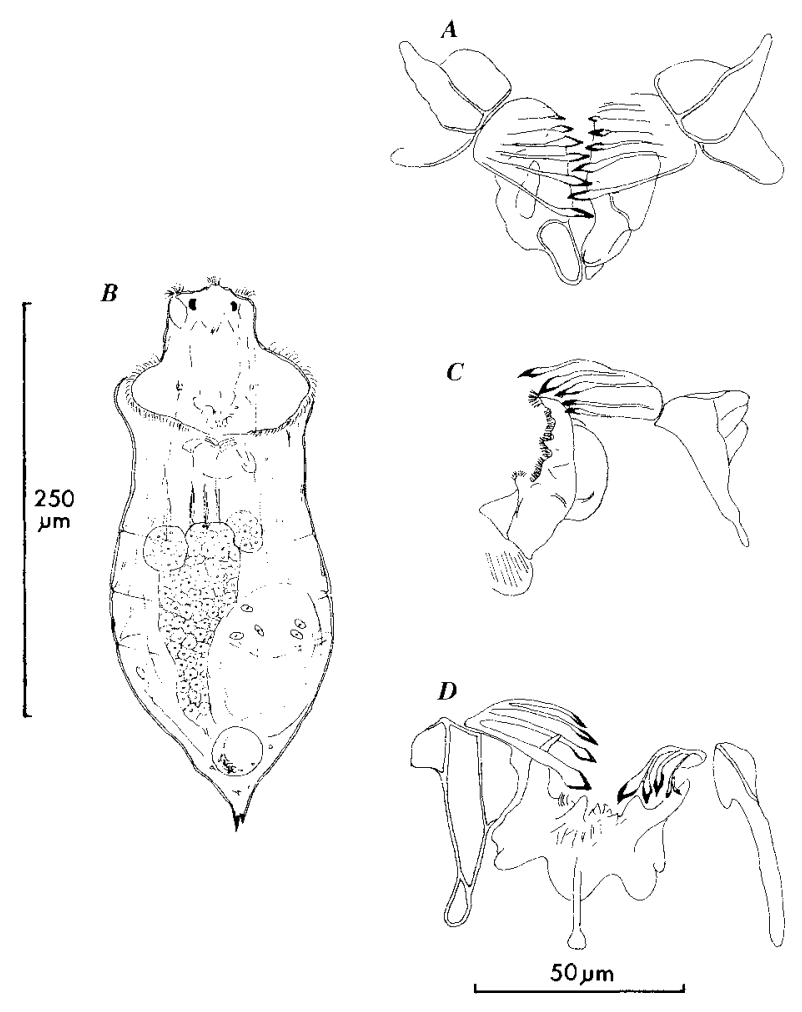

FIG. 2 - (A) Epiphanes senta: trophus. (B, C) Rhinoglena frontalis: (B) frontal view of whole animal; (C) trophus only left half shown. (D) Euchlanis sp.: trophus - note that the left manubrium has been twisted through $90^{\circ}$.

and measurements for this species (Koste 1978). Resting eggs and males were not seen.

Rhinolena frontalis is a cold stenotherm inhabiting shallow water. In the Southern Hemisphere, it has been reported from the Australian mainland by Shiel \& Koste (1979), from Tasmania (Koste et al. 1988), from New Zealand (Russell 1960) and from Macquarie Island (Dartnall 1993). The closely related $R$. fertoensis Ehrenberg has been reported from the Antarctic in the Bunger Hills (Korotkevich 1958, Kutikova 1958).

\section{Euchlanis sp. (fig. 2D)}

Just two specimens of this rotifer were found - one in each of samples 4 and 5 . The larger specimen had a dorsal plate $215 \mu \mathrm{m}$ long and long, slender toes of $83 \mu \mathrm{m}$. A single, red eye-spot is present and the mastax has malleate trophi (fig. 2D). Males and resting eggs were not seen. These specimens are very probably E. dilatata parva Rousselet, but confirmation of this will have to await the examination of more specimens.

Euchlanis dilatata parva has been reported previously from the Antarctic and Subantarctic at Signy Island and South Georgia (Dartnall \& Hollowday 1985). The Signy specimens exhibited a considerable range in size (from 240 to nearly $500 \mu \mathrm{m}$ ) while those from South Georgia were considerably smaller. Both specimens satisfy the original description by Rousselet (1892), who separated E. dilatata from $E$. parva on the basis of its small size, greater length and slenderness of the toes, and conspicuous lateral antennae. Considerable confusion exists in the literature over the differentiation into two species; indeed, Koste (1978), while retaining them as separate species, remarks that $E$. parva resembles a small form of $E$. dilatata. The situation is further confused given the fact that $E$. dilatata grows considerably in its first 24 hours of life (Liebers 1937). Dartnall \& Hollowday (1985) considered them one and the same species.

\section{Notholca bollowdayi sp. nov. (fig. 3A-D)}

This new species was found in three of the five pools (table 2). It is a medium-sized rotifer more than $210 \mathrm{~m}$ long. The stiff dorsal lorica $(200 \mu \mathrm{m})$ is oval and more than twice as long as it is wide $(92 \mu \mathrm{m})$, the greatest width being just posterior of the midpoint. It is decorated with broad striations and series of small pits in the posterior region (Fig 3C). The median and lateral spines are long and are of similar length $(22-25 \mu \mathrm{m})$. The ventral plate is somewhat smaller $(165 \mu \mathrm{m})$, flat and undecorated. The anterior margin bears the median notch present in all members of this genera. There is a single, red eye-spot. The mastax has malleate trophi used for eating diatoms and their frustules were seen in a number of stomachs. The unci have three main teeth and up to two vestigial ones.

Notholca hollowdayi belongs to the walterkostei group but lacks the posterior tab of that species (de Paggi 1982, Dartnall \& Hollowday 1985). A new/different species of Notholca has been described from almost every Antarcticl sub-Antarctic location sampled, which poses some interesting speciation and biogeographical questions. This is an area for further study.

\section{Holotype}

A microslide of a loricate female has been deposited at the Natural History Museum, London - museum registration number 1993.5119. N. hollowdayi is named after my colleague and rotifer mentor Eric D. Hollowday.

\section{Colurella colurus compressa Lucks (fig. 4A)}

This subspecies was only found in sample 4, where it was fairly common. It is a small species with lorica length c. $100 \mu \mathrm{m}$. All of the specimens exhibited the lateral compression characteristic of the subspecies compressa. The foot has three segments and two recurved toes which were longer than the foot segments. Overall, the measurements are in close agreement with the published descriptions and measurements for this species (Koste 1978).

Many authors have not differentiated C. c. compressa from the sensu-stricto $C$. colurus, so that it is difficult to determine their distribution. Both have been reported from the Antarctic before (for review, see Dartnall \& Hollowday 1985) and, more recently, Dartnall (1993) reported C. $c$. compressa from Macquarie Island.

\section{Lepadella patella (Müller) (fig. 4B)}

This small species was found only in sample 4 . It has an overall length of $140 \mu \mathrm{m}$ and breadth of $65 \mu \mathrm{m}$. The small number of specimens found agrees closely with the published descriptions (Koste 1978).

Lepadella patella is cosmopolitan and has been reported 


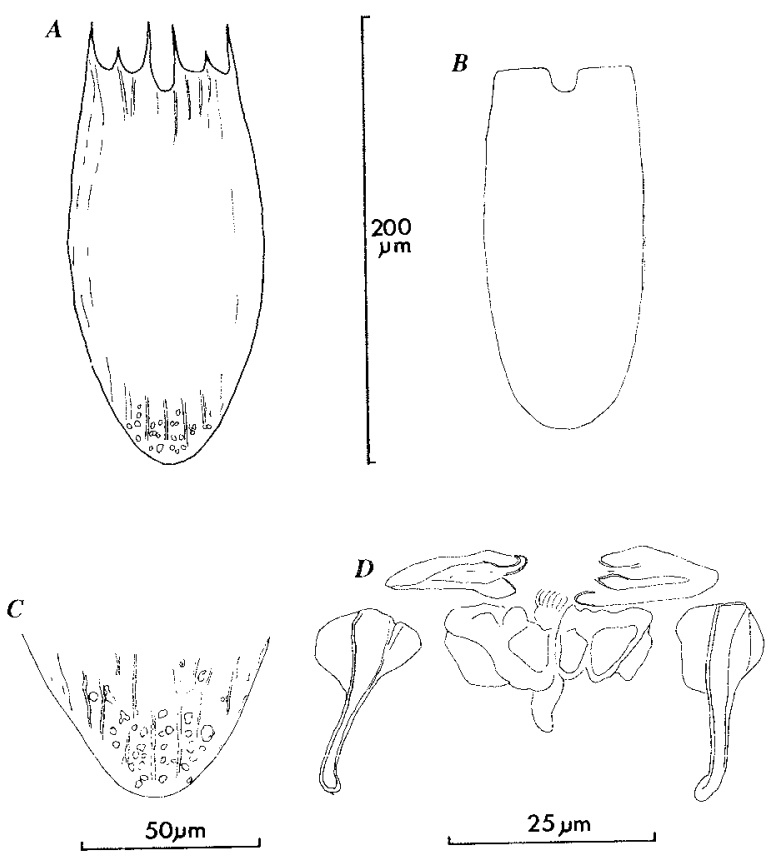

FIG. 3 - Notholca hollowdayi: (A) lorica - dorsal plate; (B) ventral plate of lorica; (C) detail dorsal lorica; (D) trophus.

from both Macquarie Island and Iles Kerguelen by Russell (1959). Other locations in the Antarctic include the Obruchev and Bunger Hills (Kutikova 1958, Korotkevich 1958), the Thalla Hills (Opalinski 1972), Langhovde (Sudzuki 1964), the Vestfold Hills (Everitt 1981) and the Larsemann Hills (Dartnall 1995).

\section{Lepadella triptera Ehrenberg (fig. 4C)}

This small species was found only in sample 4 , where it was rare. The single specimen measured had a lorica length of $75 \mu \mathrm{m}$, width $46 \mu \mathrm{m}$ and toes $21 \mu \mathrm{m}$ long, all of which are in the accepted range for this species (Koste 1978).

Lepadella triptera is cosmopolitan and has been reported from the Antarctic at Signy Island (Dartnall \& Hollowday 1985) and from the sub-Antarctic at Macquarie Island (Dartnall 1993)

\section{Lindia torulosa Dujardin (Fig. 5A)}

This large rotifer $(>500 \mu \mathrm{m})$ was found in two of the pools, where it was fairly common. It is a flexible rotifer with two small toes and a very large, red eye-spot on the brain. The specimens were only observed crawling over the bottom, so that the auricles which appear when the animal swims were not observed.

Lindia torulosa is cosmopolitan and has been reported from one sub-Antarctic and four Antarctic locations. On the Antarctic Peninsula, Beauchamp (1913) recorded it at Jenny Island, while Heywood (1977) reported a new form, L. torulosa antarctica, from the nearby Alexander Island. Since then, it has been found in the Larsemann Hills (Dartnall 1995) and from Macquarie Island (Dartnall 1993). Interestingly, it has not been found at Signy Island.

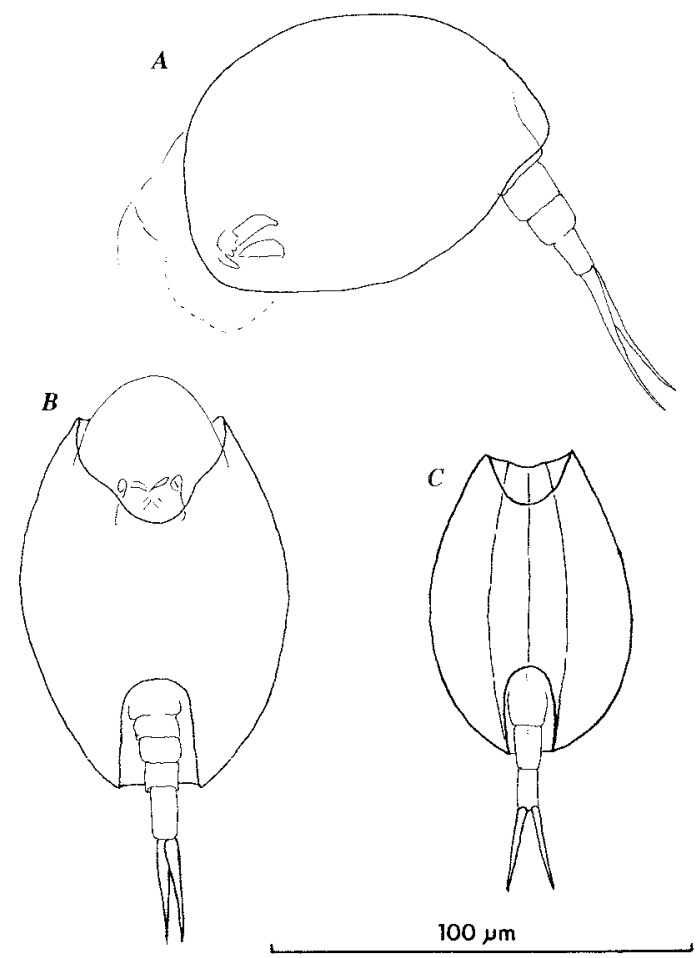

FIG. 4 - (A) Colurella colurus compressa: lateral view of lorica and foot. (B) Lepadella patella: ventral view of lorica and foot. (C) Lepadella triptera: ventral view of lorica and foot.

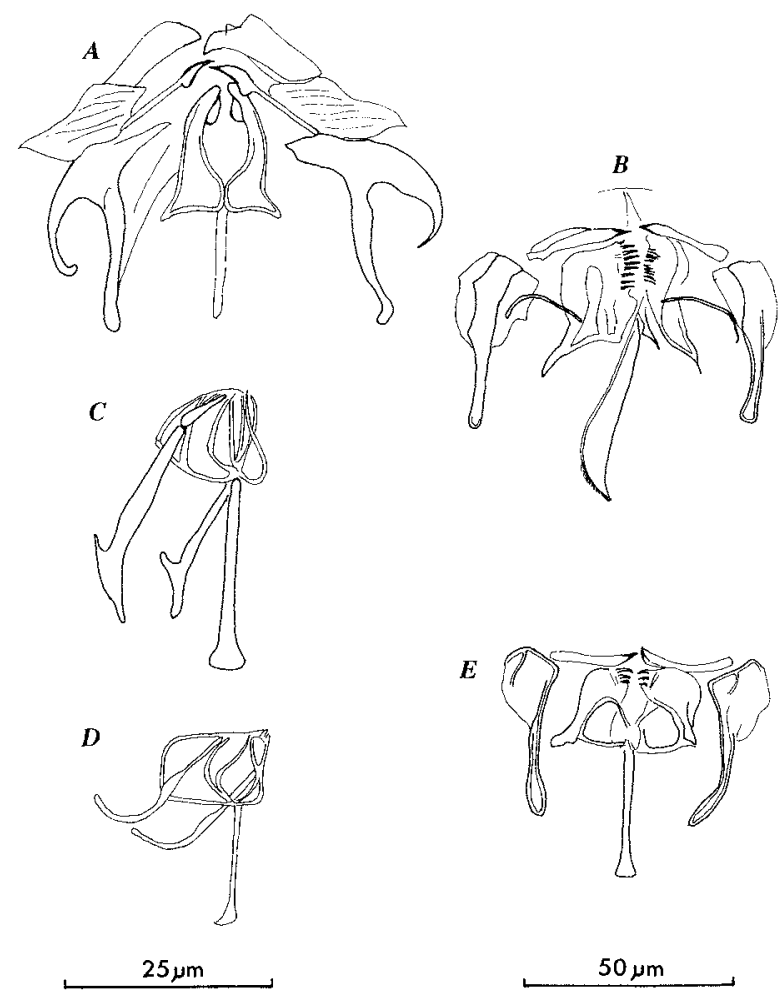

FIG. 5 - (A) Lindia torulosa: trophus. (B) Notommata glyphura: trophus. (C) Cephalodella sterea: trophus. (D) Cephalodella ventripes: trophus. (E) Resticula gelida: trophus. 
Notommata glyphura Wulfert (fig. 5B)

This large species $(>400 \mu \mathrm{m})$ was found only in sample 4 . The species was yellow in colour with a brown tinge and had a large, conspicuous, red eye-spot. The virgate trophi are relatively large: $65 \mu \mathrm{m}$ deep and $75 \mu \mathrm{m}$ across - fulcrum $38 \mu \mathrm{m}$, rami $28-30 \mu \mathrm{m}$, manubria $38 \mu \mathrm{m}$ and unci $24 \mu \mathrm{m}$. Notommata glyphura has been reported from Europe (Koste 1978), Saudi Arabia (Segers \& Dumont 1993), Senegal (de Ridder 1986), Australia (Koste \& Shiel 1980) and Macquarie Island (Dartnall 1993).

\section{Cephalodella sterea (Gosse) (fig. 5C)}

Just one specimen of this small cephalodellid was found in sample 1 . This specimen had an overall length of $168 \mu \mathrm{m}$. The body, including the foot, was $136 \mu \mathrm{m}$ long and the toes were $31 \mu \mathrm{m}$ long. The mastax has virgate trophi; the fulcrum is $21 \mu \mathrm{m}$ long, rami $10 \mu \mathrm{m}$ and manubrium $21 \mu \mathrm{m}$.

Cephalodella sierea has been reported from the Antarctic before - in the Obruchev Hills (Korotkevich 1958) and in the Larsemann Hills (Dartnall 1995).

\section{Cephalodella ventripes Dixon-Nuttall (fig. 5D)}

Two specimens of this small Cephalodella were found. The larger specimen had an overall length of $129 \mu \mathrm{m}$, with a body length, including the foot, of $98 \mu \mathrm{m}$ and toes of $31 \mu \mathrm{m}$. This is a new record for the sub-Antarctic and has now also been found in the Larsemann Hills (Dartnall 1995).

Cephalodella ventripes has been recorded from New Zealand (Hilgendorf 1902) and Tasmania (Koste \& Shiel 1987).

\section{Resticula gelida (Harring \& Myers) (fig. 5E)}

Another large, soft-bodied rotifer; the specimens found in sample 5 were up to $400 \mu \mathrm{m}$ long and are in close agreement with the published drawings and descriptions (Koste 1978).

Resticula gelida has a worldwide distribution and has been reported from the Antarctic at Adelaide Island (Dartnall 1980), from brackish pools at Signy Island (Dartnall \& Hollowday 1985), and from the Larsemann Hills (Dartnall 1995).

\section{Trichocerca brachyura (Gosse) (fig. 6A, B)}

This small, kidney-shaped rotifer was found in samples 3 and 4 . The right toe was much thinner than the left and approximately two-thirds in length $(21 \mu \mathrm{m}$ against $31 \mu \mathrm{m})$. The trophi of all the specimens measured (five) were $38 \mu \mathrm{m}$ long and very asymmetrical. The left manubrium was crutchshaped and $31 \mu \mathrm{m}$ long; the right manubrium was much shorter and spindly. The specimens found agree very closely with the published descriptions and drawings (Koste 1978)

Trichocerca brachyura is cosmopolitan and has been reported from three Antarctic and sub-Antarctic locations; from South Georgia and Signy Island (Dartnall \& Hollowday 1985) and from Macquarie Island (Dartnall 1993).
Encentrum heardensis sp. nov. (fig. 6C, D)

This new species was found in two pools (Nos 1 and 5). The body is illoricate and very flexible (up to $300 \mu \mathrm{m}$ long) and bears two short, stubby toes $(17.5 \mu \mathrm{m}$ long). The mastax has forcipate trophi which are distinctive $-50 \mu \mathrm{m}$ long and $25 \mu \mathrm{m}$ wide. The manubria have swollen bases and are $33 \mu \mathrm{m}$ long. The intramallei are small (c. $4.5 \mu \mathrm{m})$, and the unci powerful, curved ( $20 \mu \mathrm{m}$ long) and pointed. The fulcrum is short ( $14 \mu \mathrm{m}$ long) and spindly, while the rami are massive ( $20 \mu \mathrm{m}$ long), with a deep body and a pointed edge to the inner median edge. No teeth were seen on the inner edge of the rami. E. heardensis, though distinct, bears some similarities to E. mucronatum Wulfert and E. tobyhannaensis Myers.

\section{Holotype}

A microslide of a female showing the trophus has been deposited at the Narural History Museum, London museum registration number 1993.5118

\section{Encentrum mustela (Milne) (fig. 6E)}

This species was one of the commonest, occurring at three locations (table 2). The body is illoricate and very flexible. The mastax has forcipate trophi. The intramallei of most
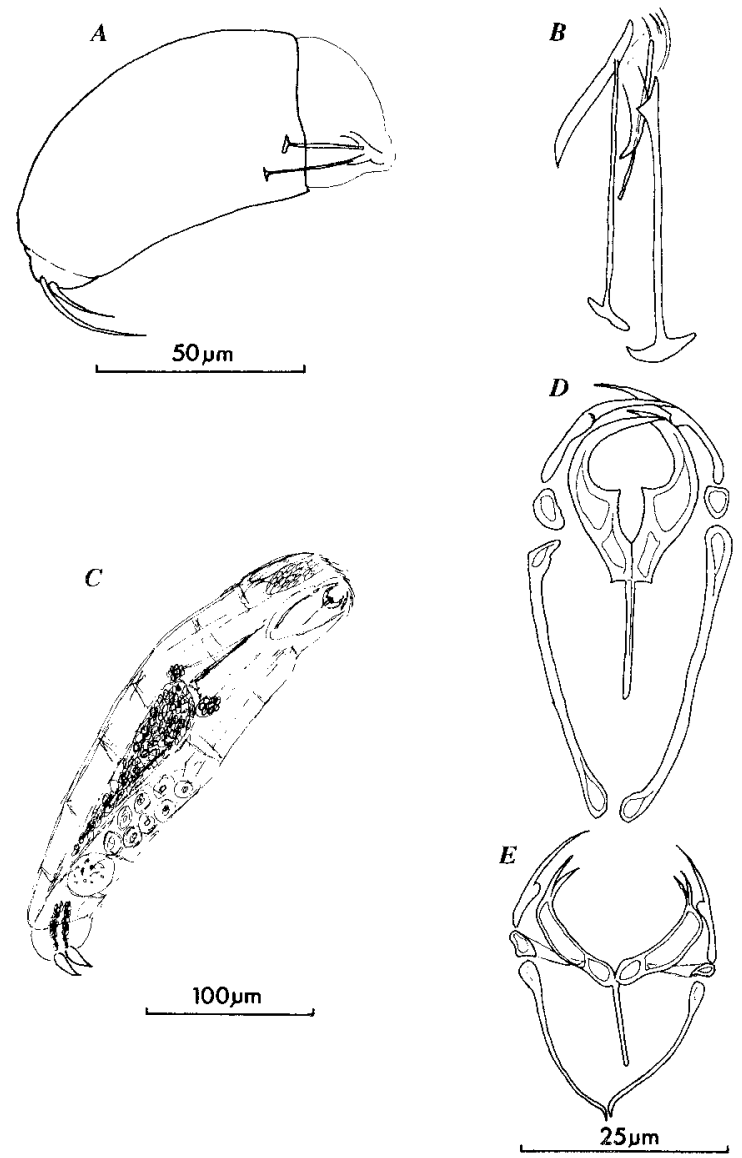

FIG. 6 - $(A, B)$ Trichocerca brachyura: (A) lateral view; (B) trophus. ( $C, D)$ Encentrum heardensis: (C) lateral view; (D) trophus. (E) Encentrum mustela: trophus. 
specimens have a delicate curved "tail" extending almost to the midline (fig. 6E). This structure, though present in many Encentrum species, has not been noted before in $E$. mustela. Previously the trophi were dissolved out in bleach - a practice that may have led to the loss of these delicate "tails"; it was not followed with the Heard Island specimens, where the whole animal was mounted in polyvinyllactophenol.

In Europe, E. mustela is regarded as a cold stenotherm. A solitary species, it probably has a circumpolar distribution. It has been reported from Signy Island (Dartnall \& Hollowday 1985), from Macquarie Island (Dartnall 1993) and from the Larsemann Hills (Dartnall 1995).
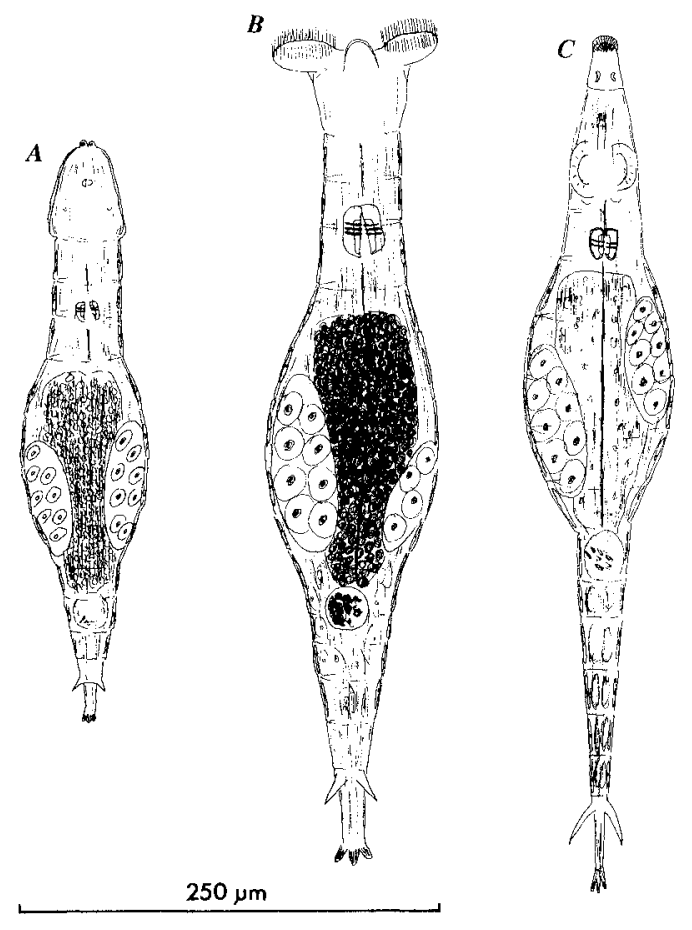

FIG. 7 - (A) Adineta sp.: dorsal view. (B) Habrotrocha sp.: dorsal view. (C) Rotaria rotatoria: dorsal view.
Ptygurasp.

A number of tube-dwelling rotifers were seen in sample 5 . They are thought to be $P$. crystallina (Ehrenberg) but confirmation will have to wait examination of additional specimens.

Ptygura crystallina has a worldwide distribution and has been reported from the Antarctic and sub-Antarctic before. It has been found at Signy Island (Dartnall \& Hollowday 1985), in the Vestfold Hills (identified as Ptygura sp. by Everitt [1981] but now confirmed as P. crystallina), in the Larsemann Hills (Dartnall 1995) and Macquarie Island (Dartnall 1993).

\section{Collotheca ornata cornuta (Dobie)}

This is one of the easiest rotifers to identify. The margin of the coronal funnel bears five knobs; the dorsal knob is longest, with a short, finger-like projection. A number of the larger specimens $(>500 \mu \mathrm{m})$ had a single oval egg $(45 \times 30 \mu \mathrm{m})$ attached to the pedicel.

Collotheca ornata cornuta is cosmopolitan. It has been reported from the Antarctic region several times and undoubtedly has a circumpolar distribution. It was first recorded in 1910 by Murray, who found it at Cape Barne and Cape Royds (reported as Floscularia cornuta [Murray 1910]), and has subsequently been reported from there and nearby by Armitage \& House (1962 - though their record is for C. ornata) and by Dougherty \& Harris (1963). It has been reported from eastern Antarctica, from pools in the Obruchev Hills (Korotkevich 1958, Kutikova 1958), from the Larsemann Hills (Dartnall 1995), from Signy Island (Dartnall \& Hollowday 1985) and from Macquarie Island (Dartnall 1993).

\section{Bdelloidea}

Adinetasp. (fig. 7A)

Just one specimen was seen in sample 4 . This specimen was $350 \mu \mathrm{m}$ long, transparent and appeared to be a juvenile. It bore no characteristic marks.

\section{Habrotrocha sp. (fig. 7B)}

This was the only rotifer found in every sample. The largest specimens were almost $600 \mu \mathrm{m}$ long and yellow-grey in colour. The trochal discs are, when displayed, not much wider than the neck, and eye-spots are absent. The dental formula is $3 / 3$. The dorsal antenna is short and the small conical spurs are joined at their bases. This would appear to be viviparous species — the largest specimen had five young developing within its body cavity.

\section{Rotaria rotatoria Pallas (fig. $7 \mathrm{C}$ )}

Another large bdelloid $(>500 \mu \mathrm{m})$, this species was found only in sample 4. It has a smooth cuticle, a large prominent rostrum with two large, red eye-spots and a dental formula of $2 / 2$. 
Rotaria rotatoria is cosmopolitan and has been reported from Europe, North, Central and South America, central and South Africa, Australia and New Zealand (Bartos 1951). In the sub-Antarctic it has been recorded from South Georgia by Dartnall \& Hollowday (1985 - they identified their single specimen as Rotaria sp., but it is now thought to be $R$. rotatoria), and from Macquarie Island (Dartnall 1993).

\section{Annelida}

A large enchytraeid worm was common amongst the samples of benthic vegetation. Similar worms have been found at Signy Island in the South Orkneys (Heywood, Dartnall \& Priddle 1979), at Macquarie Island (Evans 1970), and at South Georgia.

\section{Arthropoda}

Four cladocerans, two copepods and three species of mite were seen. The largest of these is the cladoceran Daphniopsis studeri Rühe, which has been reported before from Heard Island (Smith \& Sayers 1971), as well as from Kerguelen (Gay 1982) and in the Vestfold Hills (Korotkevich 1958) and Larsemann Hills (Dartnall 1995). The second largest cladoceran keys down to Macrothrix hirsuticornis Norman $8 x$ Brady, a species which has been reported from a number of Antarctic and sub-Antarctic locations (at Signy Island [Heywood, Dartnall \& Priddle 1979]; also at South Georgia [Dartnall \& Heywood 1980], and at Macquarie Island [Evans 1970]). The late Prof. D.G. Frey (pers. comm.) has questioned the identification of "birsuticornis" in the Southern Hemisphere, and the true identification of this species will have to await elucidation. The calanoid copepod is Pseudoboeckella remotissima Brehm. According to Smith \& Sayers (1971), the harpacticoid at Heard Island is Epactophanes richardiantarticus (Richters). Very few examples were found in the present survey and they have not yet been verified. Three species of mite, Halozetes marinus? Wallwork, Podacarus auberti occidentalis Wallwork and Algophagus antarcticus Hughes were found.

\section{DISCUSSION}

Although pool No. 4 contained the greatest number and variety of species (table 2), it is not thought to be significantly different from the other pools, when allowance is made for the different sampling methods employed (table 1) and the fact that some species are represented by just one or two specimens.

The wealth of data obtained was surprising, given the opportunistic nature of the sampling - all five pools were sampled within an hour. Similar samplings made at other antarctic locations have not been as successful. Thus, Beauchamp (1940) reported just two species of rotifer from IIes Kerguelen; Russell (1959) added a further ten, when he examined the samples obtained by Sir Douglas Mawson's British, Australian, New Zealand Antarctic Research Expedition of 1929-31, and Lair \& Koste (1984) an additional two
At South Georgia, Dartnall \& Hollowday (1985) recorded 15 species from samples collected for them. They had made an extensive study at Signy Island and recorded 38 species, 11 of which were common to both locations (Dartnall \& Hollowday 1985). They concluded that an indepth study at South Georgia would not only find most of the "missing" 27 Signy species but additional temperate ones as well.

Such an expectation would appear to be supported by the most recent results from Macquarie Island. Here, Russell (1959) had originally identified only three species of rotifer from the creek running into Lusitania Bay, but a subsequent and more thorough examination of the major water bodies there identified 39 (Dartnall 1993)

As further evidence of the successful sampling at Heard Island, the collection picked up the larger micrometazoans that had previously been identified from there - i.e. the cladoceran Daphniopsis studeri and copepod Pseudoboeckella remotissima (Smith \& Sayers 1971), the enchytraeid (Lee 1968) and the aquatic mite Algophagus antarcticus (Hughes 1955). Indeed, the overall composition of the fauna - an acoel, one species of gastrotrich, two nematodes, two tardigrades, 20 rotifers, one enchytraeid worm, and nine arthropods, made up of four cladocerans, two copepods and three mites - is very similar to the more detailed lists available for Signy and Macquarie Islands. The freshwater fauna list for Signy Island consists of an acoel, one species of gastrotrich, nematodes, tardigrades, 38 rotifers, an enchytraeid worm and 13 arthropods (an anostracan, three cladocerans, two ostracods, two copepods and five mites) (Heywood, Dartnall \& Priddle 1979, Dartnall \& Hollowday 1985, Pugh \& Dartnall 1994). That for Macquarie Island consists of a platyhelminth, two gastrotrichs, nematodes, tardigrades, 39 rotifers, two enchytraeid worms, and 14 arthropods (an isopod, five cladocerans, two ostracods, two copepods and four mites) (Evans 1970, Dartnall 1993, Pugh \& Dartnall 1994). The similarities extend to overall numbers for the various groups, even down to the level of genera.

Ostracods are notably absent from the Heard Island list. They are normally found in larger and deeper lakes than were sampled in this study. Rotifers, by virtue of their numbers, afford a more reliable basis for comparison of different locations. At Signy Island, there were 38 species of rotifer belonging to 20 genera (Dartnall \& Hollowday 1985) and, at Macquarie Island, 39 species belong to 24 genera (Dartnall 1993), with 12 species and 16 genera common to both locations. At Iles Kerguelen, 14 species belonging to 12 genera have been reported (Beauchamp 1940, Russell 1959, Lair \& Koste 1984). Kerguelen shares 11 genera and five species with Macquarie Island, and one species and nine genera with Signy Island. Heard Island, with 20 species belonging to 17 genera, shares 15 genera and 11 species with Macquarie Island, 13 genera and eight species with Signy Island, and only six genera and no species with Kerguelen.

All of this would seem to indicate that only about half the Heard Island rotifers have been found. At present, the fauna at Heard Island seems very dissimilar to its near neighbour Kerguelen and has much more in common with Macquarie Island, to the east, and South Georgia and Signy Island, to the west, but further studies are needed to clarify this. 


\section{ACKNOWLEDGEMENTS}

My thanks to Tony Flaherty for making the collections at Heard Island, and to the Australian Antarctic Division for their help and support in making this possible. I also thank Dr Geoff Boxhall of the Natural History Museum, London, for identifying the copepods; and Dr Phil Pugh and Ms Sandra McInnes of the British Antarctic Survey, Cambridge, for their help in identifying the mites and tardigrades respectively.

\section{REFERENCES}

Armmacit, K.B. \& Houst, H.B., 1962: A limbological reconnaissance in the arca of McMurdo Sound, Antarctica. Limnol. Oceanogr. 7: 36-41.

BarTos, E., 1951: The Czechoslovak Rotatoria of the Order Bdelloidea. Vest. Cesk. Spol. Zool. 15: 251-500.

Bravchamp, P. DE, 1913: Rotiferes. Deuxieme Expedition Antarctiques Française 1908-1910. 8: 105-116.

BeAlcham], P. DE, 1940: Turbellaries et Rotiferes. In Jeannel, R. (Ed.): CROISIERE DU BOUGAINVILLE AUXILES AUSTRALES FRANCAISES. Mem. Mus. Natl Hist. Nat. Ser. 14: 313-326.

Dartnali, H.J.G. , 1980: Freshwater Biology at Rothera Point, Adelaide Island: 1. General description of the pools and the fauna. Br. Antarct. Surv. Bull. 50: 51-54.

Dartnall, H.J.G., 1993: The Rotifers of Macquarie Island. ANARE Res. Notes 89: $41 \mathrm{pp}$.

DarTNALL, H.J.G., 1995: Rotifers, and other aquatic invertebrates, from the Larsemann Hills, Antarctica. Pap. Proc. R. Soc. Tasm. 129: 17-23.

Darinall, H.J.G. \& Hrywoon, R.B., 1980: The freshwater fauna of South Georgia. Br. Antarct. Surv. Bull. 50: $115-$ 118.

Darivalt, H.J.G. \& Hollowday, E.D., 1985: Antarctic Rotifers. Br. Antarct. Surv. Sci. Rep. 100: 46 pp.

De PAGGi, S.B.J., 1982: Notholca walterkostei sp. nov. y ostros Rotiferos dulceacuicolas de la Peninsula Potter. Isla 25 de Mayo (Shetland del Sur, Antartida). Rev. Asoc. Cienc. Nat. Litoral. 13: 81-95.

DE RIDDER, M., 1986: Annotared checklist of non-marine Rotifers Rotifera from African Inland waters. Docum. Zool. Mus. R. Afr. Cent. Tervuren 21: $123 \mathrm{pp}$.

Donser, J., 1972: Bericht über funde von Rädertieren (Rotatoria) aus der Antarktis. Pol. Arch. Hydrobiol. 19: 251-252.

Dolgherty, E.C. \& Harris, L.G., 1963: Antarctic Micrometazoa: Fresh-water species of the McMurdo Sound area. Science 140; 497-498.

Evans, A.J., 1970: Some aspects of the ecology of a calanoid copepod, Pseudoboeckella brevicaudata Brady 1875, on a subantarctic island. ANARE Sci. Rep. 110: 100 pp.

EverrT'T', D.A., 1981: An ecological study of an Antarctic freshwater pool with particular reference to Tardigrada and Rotifera. Hydrobiologia 83: 225-237.

GAY, C., 1982: Les eaux douces des Iles Kerguelen et leur peuplement en Entomostraces. CNFRA 51: 93-99.

HEAdland, R.K., 1989: CHRONOLOGICAL LIST OF ANTARCTIC EXPEDITIONS AND RELATED HISTORICAL EVENTS. Cambridge University Press: $730 \mathrm{pP}$.

Heywoon, R.B. , 1977: A limnological survey of the Ablation Point area, Alexander Island, Antarctica. Phil. Trans. R. Soc. Ser. B. 279: 39-54.

Herwoon, R.B. , Dartall, H.J.G. \& Priddle, J., 1979: The freshwater lakes of Signy Island, South Orkney Islands, Antarctica. Br. Antarct. Surv. Data 3: $46 \mathrm{pp}$.

Hil.gendorl: F.W., 1902: The Rotifera of New Zealand. A revised and expanded list. Trans. Proc. N.Z. Inst. 35: $267-271$.
HugHES, A.M., 1955: A new genus and species of hyadesid mite - Algophagus antarcticus - from Heard Island. ANARE Rep. Ser. BI Zool. 1: 1-19.

Kororkevich, V.S., 1958: Nasalinie vodoemov oazisov v Vostochnoy Antarktide. Inf. Byull. Sou. Antarkt. Eksped. 3: 91-98. (Paper translated into English, 1964: Concerning the population of water bodies in the oases of East Antarctica. Sov. Antarct. Exp. Inf. Bull. 1: $154-$ 161.)

KOSIE, W., 1978: ROTATORIA. DIE RÄDERTIERE MITTELEUROPAS EIN BESTIMMUNGSWERK. BEGRUNDET VON MAX VOIGT. Gebruder Borntraeger, Berlin: 2 vols.

Koste, W. \& SHm1, R.J., 1980: New Rocifera from Australia. Trans. R. Soc. S. Aust. 104: 133-144.

Kostr, W. \& Shri, R.J., 1987: Tasmanian rotifera: Affinities with the Australian Guna. Hydrobiologia 147: 31 - 13.

Koste, W., SHri., R.J \& TAN L.W., 1988: New rotifers (Rotifera) from Tasmania. Trans. R. Soc. S. Aust. 112: $119-131$.

Kunkova, L.A., 1958: K fauna kolovratok s poberezhya Vostochnoy Antarktide. Inf. Byzll. Sov. Antarkt. Eksped. 3: 99. (Paper translated inco English, 1964: Rotifers from the coast of East Antarctica. Sow. Antarct. Exp. inf. Bull. 1: 162

LnR, N. \& Koste, W., 1984: The rotifer fauna and population dynamics of Lake Studer 2 (Kerguelen Archipelago) with description of Filinia terminalis kergueleniensis n. ssp. and a new record of Keratella sancta Russel (sic) 1944. Hydrobiologia 108: 57-64.

LEE, K.E., 1968: Oligochaeta from subantarctic islands. Rep. BANZ Antarct. Res. Exped. 1929-1931. Ser. B 8: 149165 .

Llebers, R., 1937: Beiträge zur Biologie de Rädertiere. Untersuchung an Euchlaris dilatata und Prodes decipiens. $Z$. Wiss. Zool. 150: 206-261.

Murray, J., 1910: Antarctic Rotifera. In Murray, J. (Ed): BRITISH ANTARCTIC EXPEDITION. 1907-09. REPORTS ON THE SCIENTIFIC INVESTIGATIONS. BIOLOGY. VOL. I. William Heineman: 41-65, pls 9-13.

OpAIINSKI, K.W., 1972: Flora and fauna in freshwater bodies of the Thalla Hills Oasis (Enderby Land, eastern Antarctica). Pol. Arch. Hydrobiol. 19: 383-398.

Pugr P.J.A. \& Dartina, H.J.G., 1994: The Acari of freshand brackish water habitats in the Antarctic and SubAntarctic Regions. Polar Biol. 14: 401-404.

Rousselet, C.F., 1892: On Conochilus unicornis and Euchlanis parva, two new species of Rotifer. J. Quekett Microsc. Club 2: 367-370.

Russel., C.R., 1959: Rotifera. Rep. BANZ Antart. Res. Exped. 1929 1931. Ser. B 8:81-88.

Rusiele, C.R., 1960: An indcx of the Rotatoria of New Zealand and outlying islands from 1859 to 1959. Trans. $R$. Soc. N.Z. 88: 443-461

Russti., C.R., 1961: A simple method of permanently mounting Rotifera trophi. J. Quekett Microsc. Club 5: 384-386.

Sfgers, H. \& Dumonr, H.J., 1993: Rotifera from Arabia, with descriptions of two new species. Fauna of Saudi Arabia 13: 3-26.

Shite, R.J. \& Kosit, W., 1979: Rotifera recorded from Australia. Trans. R. Soc. S. Aust. 103: 57-68.

Smili, W. A. \& Sayers, R.L., 1971: Entomostraca. In Van Zinderen Bakker, E.M., Winterbotrom, J.M. \& Dyer, R.A. (Eds): MARION AND PRINCE EDWARD ISLANDS. Report on the South African Biological and Geological Expedition 1965-1966. A. A. Balkema, Cape Town: 361-372

SunzLKI, M., 1964: On the microfauna of the Antarctic region, 1. Mosswater community at Landhovde. JPN Antarct. Res. Exped. Sci. Rep. Ser, E Biol. 19: 1-41.

(accepted 15 June 1994) 